\title{
Interaction with Prophetic Tradition: A Review of al-Qaradawi's Thought
}

\section{Abur Hamdi Usman}

Nazneen Ismail

Zainora Daud

Rosni Wazir

Academy of Islamic Studies, International Islamic University College Selangor, Malaysia Corresponding Author Email: aburhamdi@kuis.edu.my

\section{Doi:10.5901/mjss.2016.v7n1p547}

\section{Abstract}

\begin{abstract}
As a scholar who was raised by Islamic movement (harakah) Muhammad Yusuf al-Qaradawi has a rich experience in interacting with the Prophetic tradition, he also has more direct contact with the public until have a comprehensive understanding of the situation in the community. Hence, not be surprised if in the hadith assessment his highlight more about the process of getting appropriate recognition of a tradition. According to him the imbalance between the validity of sanad with matan resulted from errors using the framework to interact with the hadith. The postulate of Hadith is final, without it Quran can not be well understood. Thus, this paper discusses al-Qaradawi, his attitude and method to al-Sunnah and how to interact with it.
\end{abstract}

Keywords: al-Qaradhawi; Prophetic Tradition; Interaction

\section{Introduction}

As one of the main sources of Islamic studies, Hadith is bayan (explanation) to the verses of the Qur'an which stills mujmal (global), 'am (general) and mutlaq (without limitation). Even the hadith independently can be a function as setter (muqarrir) of law that has not been prescribed by the Quran (Munawwar \& Mustaqim, 2001). Hadith as a source of Islamic teachings seems always interesting to study further, whether concern the authenticity or validity (sanad and matan) as well as the methodology of understanding (syarh) the hadith itself. Previous scholars have been trying to learn or understanding the hadith that found in al-Kutub al-Sittah, by writing a book of interpretation about the book.

Nonetheless, the effort to find a method used by scholars of hadith in the preparation of syarh book has almost never touched. But some of the methods used by the scholars in compiling the syarh book of hadith, could be classified into several methods of understanding, namely tahlîî, ijmâlî, muqârin and maudhû'i. These methods adopted from the method in interpretation of Quran by finding common character among the interpretation of Quran or Hadith. It means that the method of interpretation Quran could be implemented onto the interpretation of hadith by changing the words/sentences in the Quran with the hadith. Meanwhile, in terms of validity of hadith because it was quite a long time from the death of the Prophet to the time of collecting them as a book, thus so many people were questioned about the authenticity, originality, accuracy, and the truth of the hadith. Therefore, there was arising sciences that serve to investigate or criticize the validity of the narrator, sanad, and matan of hadith. Problems of hadith if it can be parsed, covering a lot of things; start from the authenticity that sued by many orientalists, widening to the transmission (isnad), history of verbal tradition changes from codification into text of hadith, until to the problem of understanding and meaning. These problems occupy an important position as well as giving substantive revaluatif spirit and reinterpretatif to various understanding and interpretation of hadith. This understanding problem then tries to be find solution by the observer and scientists of hadith who were trying to understand matn of hadith with different methods. One of them was Yusuf alQaradawi, who tried to offer a method to understand the hadith.

Hence, Helfont (2010) notes that much of al-Qaradawi's influence can be attributed to his embrace of modernity, which has proven very popular among may Muslims who wish to live modern live, yet not shed their Islamic identity. Like other scripture-based religion, Islam's sacred texts has been interpreted differently throughout history. Al-Qaradawi's skill in reinterpreting them to fit the contemporary world has been vital to his success. He determines what is "Islamic" not only 
through considering classical Islamic sources, but also through considering the situation and needs of modern Muslims.

\section{Yusuf al-Qaradawi: Life and Thought}

Among the Muslim scholars, al-Qaradawi is known as the Islamic scholar and thinker who have special characteristics. Heis unique and privilege because al-Qaradawi has special ways and methodologies in conveying the message of Islam. Because of his methodology, he is admittedby the Western world as an Islamic thinker who always displays Islam in a friendly way, polite and modest. By his capacity that makes al-Qaradawi often invited to the international religion meetings in Europe and America, as the representative of the Islamic group (Talimah, 2001).

Al-Qaradawi was born in a small village in Egypt named Shaft Turab in the middle of the Delta on 9 September 1926. He has memorized the Qur'an at the age of ten years. After completing his education in Ma'had Thanawi Thanta, al-Qaradawi then proceeded his study to Al-Azhar university, Faculty of Islamic Theology and finished in 1952, but he obtained his doctoral degree in 1972 with a dissertation "Zakat And Its Impact on Poverty Alleviation", which was then refined into figh zakat, a comprehensive book discusses modern issues on zakat (Suryadi, 2008).

Reason for the delay in reaching his doctorate degree was he had to leave Egypt due to the cruel regime at the time. He was forced to move to Qatar in 1961 and then initiated the establishment of Faculty of Sharia at Qatar University. At the same time, he also established Center for the Study of History and Sunnah of the Prophet. He got Qatari citizenship and made Doha as a place of residence.

In the journey of his life, al-Qaradawi ever received "education" prison since from his youth. While Egypt runs by King Faruk, he was entered prison in 1949 when he was just 23 years old regarding of his involvement in the Muslim brotherhood movement. In April 1956, he was arrested again during a June Revolution in Egypt. Then in October he was back in a military prison for two years (al-Qaradawi, 2002).

Al-Qaradawi is known for his preaching and was banned as preacher at a mosque in the area of Zamalik. The reason was because his preaching creates public opinion about the in justice regimeat the time. Al-Qaradawi was motivated to produce a work containing basic principles and characteristics as well as common rules that are essential for understanding al-sunna with proper understanding. The work is entitled "Kaifa Nata'amal Ma'a Al-Sunnah Al-Nabawiyya Ma'alim Wa Dhawabith". The expectations in his book was a "maximization" understanding of Sunnah as a counterpoint on minimization of understanding by part of people who just dwelling on harfiyah understanding, an understanding that only touches the surface soul. However, this maximizing does not mean exceed the limits as termed by al-Qaradawi with "enter the house without going through the door".

According to al-Qaradawi (1999a) al-Sunnah is the interpretation of the Quran in practice or application of teachings in Islam factually and ideally, which has comprehensive (syumul) manhaj, balanced (Tawazun) and easier (muyassar). All three of these characteristics will bring a thorough understanding of the hadith.

On this basis, al-Qaradawi also established three things that should be avoided in interacting with the Sunnah, firstly, the extreme deviation. The second, astray people manipulation, (Intihal al-Mubthilin), which is the falsification of Islamic teachings by making various kinds of bid'ah which clearly contrary to the faith and shari'a, and the third, the interpretation by the fools (ta'wil al-jahilin). Therefore, a proper understanding of Sunnah is taking a moderate stance (wasathiya), which is not excessive or extreme, not to be misguided group, and not to be a group of stupid (Suryadi, 2008).

To implement his method, al-Qaradawi (1999b.) applied method by understanding hadiths by gone through the basic principles when interacting with Sunnah, such as;

- To examine the originality of hadith in accordance with general references set by the believed hadith experts, both sanad and matan.

- Understanding Sunnah in accordance with the knowledge of language, context, asbab al-wurud of hadith to determine the exact meaning of hadith.

- Ensure the assessed Sunnah does not conflict with stronger hadiths or verses.

In relation to this, some scholar sees al-Qaradawi's views of Islam as a rational, comprehensive and easy way of life appeal to large sections of Muslims worldwide. A champion of ijtihad, al-Qaradawi is committed to a religious reform that builds on the modes of reasoning of the classical Islamis tradition and takes into consideration the contemporary reality and interests of the Muslin in globalised and pluralist world. He has come under attack from more conservative scholars for his willingness to contextualise traditional Islamic norms, and from modernists for reaching conclusions that often fall short of liberal standards. al-Qaradawi has, in turn, depicted his conservative interlocutors challengers as neglectful (of mankind's duties to God), claiming for himself the position of moderation (Caeiro \& Graff, 2014). 


\section{Al-Qardawi's thought of Hadith}

In Baroudi's paper who examined the perspectives on international relations of al-Qaradawi, and argued that alQaradawi's views are central to how Islamists conceptualize international relations; and that they intersect with the views of secular Arab nationalists, Third World and Western critics of the prevailing international order, as well as neoclassical and righteous realists (Baroudi, 2014). Another interesting values from this leading contemporary Islamist thikers, alQaradawi, it further asserts that the law of mutual restraining -derive from the Qur'an-bears a major affinity to realism's balance of power principle. It argues that Qaradawi articulates a non-western variant of realism that this article refers to as Islamic realism. From the study of al-Qaradawi's thought also, the realism should not be viewed as exclusively a product of European experiences and western 'secular' thought, but as a mode of theorizing about international relations that transcends cultural boundaries. In addition, it underscores the links between religion and realism, calling for research into the likely sources of realism in the three Abrahamic religions (Baroudi, 2015).

In relation to this, there are four categories in contemporary times comprised by Muslim in their approach to Hadith: those who totally reject its relevance in Muslim life; those who blindly accept all apparent hadith regardless of their authenticity; those who indiscriminately select Hadith for practical purposes; and those who believe in the sanctity of Prophetic traditions but who carefully approach them regarding their logical and practical relevance to Islamic life and civilization (Khan, 2012). In side of hadith scholar there are two perspectives from the contributions of scholars in the matter oh hadits: the chain of narrators and the text. Hadith experts developed five universally acceptable criteria to determine the credibility and authenticity of Hadith: chain continuity (Ibn Kathir, 1994), integrity of narrators' character, report precision (Tahan, 1984), non-deficiency (Al-Suyuti, 1989), and non-aberrance (Ibn Kathir, 1994). Refer to alQardawi (1998), Sunnah is detailed manhaj for Muslim and Muslim communities life which is the interpretation of the Qur'an in practice or Islam in concretely translation. Here are the Al-Qardawi's methods on how interact with Sunnah:

\subsection{Understanding Hadiths guided by the Quran}

To understand Sunnah well, far from deviation, fraud, and wrong interpretation, we must understand them in accordance with the instructions of the Quran, i.e in the frame of Allah's guidance where truth and justice are definite:

"The word of your Lord (al-Qur'an) as right and fair sentences has completed. No one can change His words, and He is the Hearing, the Knowing." (QS. Al An'am: 115).

Quran is the spirit of Islam and the foundation of its building. It is a God constitution that becomes a reference for any legislation in Islam. Then the Sunnah is a detail explanation of the constitution, both theoretically and practically. Understanding the Hadith according to the instructions of Quran based on argument that Quran is the main source which occupies the highest place in the overall Islamic doctrial system. While Hadith descriptives of the principles in the Quran. Therefore, the Hadith and the contextual significance cannot contradict with the Quran (al-Qaradawi, 2007).

If there is a conflict, then it can happen because of the hadith is invalid or improper understanding, or what is expected as the opposition is false and not essential. If that happens, then the duty of a Muslim is doing tawaqquf if it finds that contrary to the verses of the Quran as long as no interpretation is acceptable. On that basis, the fake hadith is known as the hadith gharaniq. That kind of hadith clearly is rejected as contrary to the Quran and that is threatening from the musyrik with their "fake gods":

So what should you (O Pagans) considered Al-Latat and Al-Uzza, and the third manat, the lattest (as a daughter of God)? Is it (Should) for you (children) male and to God (child) female? That would have an unfair distribution. These are nothing but names which you and your fathers have invented it; Allah did not send down any authority to worship it. They follow nothing but conjecture and what their own souls desire, and indeed has come to them Guidance from their Lord" (QS. An-Najm: 19-23).

How it is possible, in the verses contains censure and condemnation of the statues, but there are also phrases praising them, for example: That statues/idols (gharaniq) are noble and their intercession is expected. Al-Qaradawi (2001) denies this hadith, he says, it is impossible in the sequence of the verses that contain repudiation and condemnation of the statues are inserts that praised him. 


\subsection{Collecting Hadiths with a specific themes}

Understanding the Sunnah according to al-Qaradawi (2007) can be done by collecting authentic traditions associated with a specific theme. After gathering hadiths that have the same theme, the next step is to restore the mutasyabih contents to the muhkam, connect the mutlaq and the muqayyad also interpret the general with a special. This method is a necessity because of the hadith serves as an interpreter of the Quran and descriptive meanings with detailing, interpreting, specialized and limit what is stated by the Qur'an, then of course these provisions are also applied for each hadith.

Example that appointed by al-Qaradawi (1999b.) to clarify this effort was the theme of the law to wear saroong below ankle. The first step is forward some hadiths about the reproach against people who wear saroong below ankle. Then mention hadiths pertaining to people who wear saroong below ankle. Then mention the hadiths associated with people who wear saroong below ankle without vanity. Furthermore, he displayed hadiths that describe reproach people who stuck saroong or clothes because of pride.

In addition, al-Qaradawi (1991) also revealed explanations of various scholars, including Ibn Hajar and al-Nawawi. Ultimately conclude by bringing the hadiths with the dalalah muthlaq on dalalah muqayyad hadith, that the threat to act out saroong below ankle was limited to those who do it because of vanity and pride alone. If saroong through the ankle because of the culture and then exclude these threats. Religion concerns, in this case, are the intention and motivation behind the inner physical act. It is strongly opposed by religious such are arrogance, pride, arrogance, contempt of others, and other mental illnesses. Besides, business models and forms of dress associated with the traditions and habits of human beings, which often varies according to climatic differences between hot and cold, between rich and poor, between the able and not, types of clothing, levels of life, and a variety of other influences.

\subsection{Combine (Tarjih) between Contrary Hadiths}

In principle, Nash (laws) of syariah, is not possible opposite each other. When there is a conflict, it can be eliminated by combining or customizing between the two texts, it is better than do tarjih between them. This is due, tarjih means that to ignore one of them, and prioritize the rest. An example is the hadith of Umm Salamah narrated by Abu Dawud and atTirmidhi, which forbids woman, sees a man even though the man is blind. The hadith contrary to the Hadith of Aisha and Fatimah bint Qais were both rated shahih:

From Umm Salamah, she said, I and Maimunah with the Prophet Muhammad (PBUH). Then Ibn Umm Maktoum came. When it came down command to wear hijab, The Prophet said to us, 'Veils in front him!' We said, 'O Messenger of Allah, is he blind, unable to see and recognize us?' Then the Prophet replied, 'if you both are blind as well? Don't you can see him?"

This hadith, although deemed authentic by at-Tirmidhi, but there was Nabhan the chain, maula Umm Salamah. His identity was unknown (majhul) and are not considered reliable (tsiqah), except by Ibn Hibbaan. Adh-Dhahabi in al-Mughni put it in a weak narrator. This hadith also contradicts the Hadith of Al-Bukhari and Muslim, which allows a woman to see a man who is not muhrim.

Meaning:

"From aisyah r.a, she said, he covered me with his mantle as I was to see people playing in the mosque Habasyah"

Al-Qadi lyad said, "This hadith enable women to see the activities done by men who are not mahram. The things that do not like are seeing the beautiful body part and enjoy it. "This is confirmed by the hadith Al-Bukhari and Muslim from Fatima Bint Qays that the Prophet said to her, when she divorced by her husband.

"Stayed at home during the time of your iddah. Ibn Umm Maktoum, He was a blind man."

Therefore, you can take off your shirt because he did not see. Previously, he had suggested to her to pass the time waiting at home ummu Sharik, and then he said, "It is a woman who often visited friends. We recommend that you stay at home Ibn Umm Maktoum"

In commenting on the hadith of Umm Salamah, Imam Al-Qurtubi said, "if we rely on the authenticity, it shows a firm stance on the wives of the Prophet in keeping their honor, as the hijab issue, therefore, that the philosophy is the meaning of the hadith Sahih that the Prophet ordered Fatimah bint Qais to pass the time at home waiting period Umm 
Maktoum. This means the way mergers between weak hadith with the authentic".

Al-Qurtubi commented: some scholars make this Hadith as proof that women can see a part of the male body, as may be seen of men over women, such as the head, where hang earrings. While parts including genitals still not allowed. One of the important things for a good sunnah is to adjust the hadiths that seem contradictory and combines tradition with each other traditions that have the same theme, putting each hadith according to its place so that it becomes an integral and complementary, not contradictory. Abdul Wahab Khalaf stated, in the presence of a compromise between two such arguments and allowed to practice the proposition that it was better than just functioning one proposition only. Therefore Yusuf Qaradawi analyzes it with:

- Consider the background, a situation when the hadith was pronounced, and its purpose.

- Distinguishing between facilities that are not fixed and fixed targets.

- Distinguishing between real and meaningful phrases that are majaz in understanding the hadith.

- If the settlement is deemed to collide two arguments that are not able to be resolved in three ways above, it is reached by way of a fourth, namely by leaving two such arguments. As for how to leave both the proposition that collide, there are two forms, namely: Tawaquf (suspend), suspend the practice of the argument while waiting for the possibility of other referrals to the practice of one of the two. And Tasaquth (each fall), leaving both the argument and look for other arguments to be carried out

\subsection{Understanding Hadith accordance Background, Situation, Conditions, And Purpose}

To understand exactly hadiths required knowledge of the specific causes behind the emergence of hadith, which can be found accompanying illat. If this is not taken into consideration, then the understanding will be incorrect and far from the goal syar'i. This is because the hadith of the Prophet were solutions to the problem are local, particular, and temporal. By knowing this, one can perform separation between the public, temporary and eternal, between the universal and the particular.

In view of al-Qaradawi, if the conditions have changed, and there is no illat again, then the law that intersects with a Nash will be void. Likewise, the hadith which based on a custom temporary prevailing at the time of the Prophet and undergo changes in the present, then the taken meaning is the intentions that contain restraints and not the literal intent. Example, The Prophet said:

\section{"You are more learned of the matter of your world."}

This hadith is not accurate when interpreted for the business world, the Messenger fully surrendered to the Muslims because in many fields: economic, social, political, etc. The Prophet gave a clear line. This hadith must be understood according to the specific reason with him, that the businesses of pollination date, the Medinan farmers were more expert than the Prophet. So, farmers are more aware of about than those who are not farmers. Traders are more aware about trade then farmers. The Prophet instruction about respect professional expertise or area of expertise is universal. Other examples, such as the hadith:

\section{No woman should travel except in company of a (Mahram)}

It is not completely right if this hadith interpreted that every woman (when and where) are not allowed to travel alone, she must be accompanied by her mahram. The illat of this hadith really concerns that there will be fitnah and danger to women who traveling alone to go through the desert and might be many criminals along the way. Therefore, when conditions were safe and worry has gone, it is fine women traveling alone.

\subsection{Distinguishing Between Medium Changed But Goals Remain.}

To avoid errors in understanding the hadith, must be able to distinguish between medium and target or goal. Most errors found typically assume they are the same. That goal was supposed to be our guidance but not the medium, which may change at any time.

Examples, The Prophet said:

\section{The Hijama (cupping)is the best of your remedies}

This hadith tells us that the best drug is cupping. Cupping is a tool, when it has found a better medicine, cupping is 
no longer considered as the best, and this does not violate the hadith. According to Yusuf al-Qaradawi, the recipe mentioned in this hadith is not the "spirit" of the treatment of the Prophet. The spirits are maintaining the health of human life, safety body, power and the right to rest if tired, and treated if sick. Medication does not conflict with faith in destiny or resignation to God.

The tool is always changing from time to time, from one place to another. In fact it should be changed, even if the hadith determining a particular device, it is intended to explain a reality, not to bind us with, or restrict us with any other medium.

\subsection{Distinguishing Between Haqiqah and Majaz Phrase}

Arabic Language is often used phrase in the form of Majaz (figurative, metaphorical). In science of balaghah stated that the expression in the form of Majaz, more effective than in the usual form. The noble Messenger is one of the most Arabic speakers that mastery balaghah. His speeches were part of the inspiration and it was no wonder that His hadiths, mostly used Majaz, to reveal his intentions in an impressive way.

Meaning herein include Majaz Lughawi, 'aqli, isti'arah, kinayah, and many other expressions that do not show the true meaning directly, but can only be understood by a wide range of indications accompanying approach, both textual and contextual.

In certain circumstances, sometimes understanding based on Majaz is a must. If you do not understand its meaning based on Majaz, it would deviate from the intended meaning and will bring in confusion. When the Prophet said to his wives:

"The one who the fastest follow me is the one who have longest hands"

They thought that was a person with the longest hands. Therefore, just as Aisha r.a; they measured, which one of them has the longest. In fact, according to some reports, they took a piece of bamboo to measure whose hands the longest?

In fact, the Prophet did not mean it like that. What was meant by the words of his "longest hand" is the most kind and generous. The Prophet Muhammad was indeed fit the facts in the future. Among his wives fastest-died after he was Zainab bint Jahsh-ra she was known as a woman who was very skilled, working with his hands and likes to charity.

\subsection{Distinguish the unseen (Ghaib) and the seen (The Real)}

If you look at the content of the hadith, there are many hadiths that talk about the things unseen, among them, such creatures that cannot be seen by the senses, the grave, including mizan afterlife, masyar, and hisab. Hadiths are authentic quality about this kind of thing, for al-Qaradawi (1999a.) remains shall be accepted. Not justified refusing such hadiths simply because it can not be experienced by humans (empirical experience). While still within the limits of possibility in mind, it is still acceptable.

"In the heaven there are trees that if a rider passed under it for a hundred years, it is not enough to pass it through"

The hadith narrated by Al-Bukhari and Muslim from Sahl bin Sa'd, Abu Said and Abu Hurairah. Al-Bukhari also stated from Anas. Therefore, when interpreting the word of God: "wa dzillin mamduud" (in the shadow of the sprawling), Ibn Kathir says that the hadiths it really comes from the prophet Muhammad; even included as hadith mutawatir which confirmed its authenticity by rating of hadith experts.

As it appears, a hundred years referred to the above hadith is a measure of the world. And no one knows the ratio between the world time and time in the sight of Allah, except Allah. In the Quran it is stated:

"And indeed one day with your Lord is like a thousand years in the calculation" (QS. Al-Hajj: 47)

When this hadith is authentic, we can only say with confidence, "we believe it" that in the next life there are special rules that are very different from the formation of the world.

\subsection{Ensure the words meaning of the hadith}

Ensuring meanings and connotations of words is very important in understanding the hadiths. Therefore, the connotations 
of certain words sometimes change from one time period to another, from one environment to another environment. An example is the meaning of words mushawwir and tashwir.

These words that always be found in the authentic hadith, which has meaning are drawing and shadows drawer, and now known as sculpt and sculptors. But with the development of literature, currently word mushawwir and tashwir in the hadith will be interpreted as threatened and very painful threat are could be meant shooting and photographing $I$ photographers.

Therefore these words should not be interpreted as meaning that developed now, but should be returned to the original meaning. This photo graphic technology and not yet known at thetime of the Prophet then it is impossible to be interpreted as a photographer. So, enter the word threat is not appropriate in a photo expert. And this was what makes alQaradawi to be careful in ensuring the meaning of a particular word in the hadith.

\section{Conclusion}

Methods offered by al-Qaradawi in understanding sunnah as follows:

- Understanding hadith accordance directive of the qur'an

- Gathering hadiths with the same theme

- Incorporating or tarjih the contrary hadiths

- Understanding hadith accordance with the background, situation, conditions, and purpose

- Distinguishing between changed medium and fixed goals

- Distinguishing between haqiqah and majaz phrase

- Distinguishing the unseen (ghaib) and the real

- Ensure the meaning of words in hadist

All of these methods show to us that the best way of doing interaction on Hadith in the view of Qaradawi is the reviewer must understand the traditions in carrying out its functions. Hadith have a particular method in providing guidance for mankind:

i) Comprehensive method. A method which reflects that tradition addresses all aspects of human life, from birth to death even since become a cell. In the hadith is also discussed aspects of divinity (human relations and God), humanity (human nature). This is what must be kept in mind by all mankind.

ii) The balance method (Minhaaj Mutawaazan). A method which has a characteristic to always support the balance in human beings, namely the balance between spirit and bodily, mind and heart, the world and the hereafter, theory and practice, supernatural and real, freedom and responsibility, personal and pilgrims, and between followers and creators.

iii) Simplicity methods. A method which is defined in the running of its provisions, which is based on tolerance and easiness; Sunnah will not give undue burden.

Admittedly, offer understanding of tradition and implementation methods as mentioned by al-Qaradawi has given considerable contribution in answering the question of Muslims today especially both the methods and contens of his time. Method and content correlation are very closely, in side the method applied in the content. Contextual understanding of the traditions in the present and for the future is a necessity. Contextualization of the Prophet teachings made flexibly and rationally in accordance with contextual teachings. However, contextualization methoid must be done carefully, especially related to faith, worship and unseen matters (ghaib). In addition, contextualization should consider the universal aspect, the local and particular or specific circumstances.

\section{References}

Al-Qaradawi, Y. 2007. Pengantar Studi Hadist [Introduction to the Study of Hadith]. Bandung: Pustaka Setia. Al-Qaradawi, Y. 2007. Al-Madkhal Li Dirasah al-Sunnah al-Nabawiyyah. Bandung: Pustaka Setia.

Al-Qaradawi, Y. 2002. Shahwah al-Islamiyyah baina al-Juhud wa al-Thatarruf. Jakarta: Pustaka Al- Kautsar. Al-Qaradawi, Y. 2001. Bagaimana Berinteraksi dengan al-Quran [How to interact with the Qur'an]. Jakarta: Gema Insani Press.

Al-Qaradawi, Y. 1999a. As-Sunnah Sebagai Sumber IPTEK dan Peradaban [As-Sunna as a Source Science and Civilization]. Jakarta: Pustaka Al-Kautsar.

Al-Qaradawi, Y. 1999b. Bagaimana Memahami Hadis Nabi saw [How to Understand the Hadith of the Prophet]. Bandung: Krisma.

Al-Qardawi, Y. 1998. Al-sunnah Mashdaran Li al-Ma'rifah Wa al-Hadharah. Jakarta: Pustaka Al Kautsar.

Al-Qaradawi, Y. 1991. Kaifa Nata'amal Ma'a al-Sunnah al-Nabawiyyah Ma'alim wa Dhawabith. Cairo: Maktabah Wahbah.

Al-Suyuti, J. 1989. Tadrib al-Rawii. Beirut: Dar al-Kutub al-Ilmiyyah.

Baroudi, S. E. (2015). The Islamic Realism of Sheikh Yusuf Qaradawi (1926-) and Sayyid Mohammad Hussein Fadlallah (1935- 
2010). British Journal of Middle Eastern Studies, 1-21.

Baroudi, S. E. (2014). Sheikh Yusuf Qaradawi on International Relations: The Discourse of a Leading Islamist Scholar (1926-). Middle Eastern Studies,50(1), 2-26.

Caeiro, A. \& Graff, B. 2014. The European Council for Fatwa and Research and Yusuf al-Qaradawi. In Peter, F. and Ortega, R. (Eds.). Islamic Movement of Europe: Public Religion and Islamophobia in the Modern World. New York: I. B Tauris and Co.Ltd.

Helfont, S. 2010. Islam and Islamism Today: The Case of Yusuf al-Qaradawi. E-Notes, Foreign Policy Research Institute, www.fpri.org, Januari.

Ibn Kathir, A. F. 1994. Al-Ba'ith al-Hathith. Beirut: Dar al-Kutub al-IImiyyah.

Khan, I. A. 2012. Authentication of Hadith: Redefining the Criteria. Herndon: The International Institute of Islamic Thought (IIIT).

Suryadi. 2008. Metode Kontemporer Memahami Hadis Nabi Perspektif Muhammad al-Ghazali dan Yusuf al-Qardhawi [Contemporary Methods for Understanding of Hadith by Muhammad al-Ghazali and Yusuf al-Qaradawi Perspectives]. Yogyakarta: Teras.

Tahan, M. 1984. Taysir Mustalah al-Hadith. Kuwait: Maktabah Dar al- Turath.

Talimah, I. 2001. Manhaj Figh Yusuf al-Qardhawi. Jakarta: Pustaka al-Kautsar.

Munawwar, S. A. \& Mustaqim, A. (2001). Asbabul Wurud. Yogyakarta: Pustaka Pelajar. 